\title{
LINGKUNGAN DAN PELESTARIANNYA DALAM PRESPEKTIF ISLAM
}

\author{
Mochamad Imamudin \\ Fakultas Sains \& Teknologi UIN Maliki Malang \\ Email: imoed692@yahoo.co.id
}

\begin{abstract}
Abstrak
Masalah lingkungan dan pencemarannya merupakan masalah yang dihadapi oleh manusia saat ini dan belum ditemukan solusi yang jitu untuk memecahkannya secara komprehensif, baik dari segi cara mengontrol penyebabnya ataupun mengurangi sebab-sebabnya, meskipun usaha itu sudah dilakukan oleh organisasi lingkungan hidup dengan segala upayanya, bahkan masalah pencemaran lingkungan ini selalu dibahas oleh masyarakat internasional. Salah satu permasalahan yang mereka bahas adalah timbulnya lubang pada lapisan ozon yang mengancam terjadinya bencana yang lebih luas pada lingkungan dan dapat berdampak pada timbulnya berbagai penyakit bagi manusia. Jika peradaban modern saat ini telah menimbulkan pencemaran udara tanpa memikirkan dampaknya, maka sebenarnya Islam telah meletakkan dasar-dasar hukum, jauh sebelum timbulnya berbagai pencemaran yang timbul sekarang ini. Namun permasalahannya adalah kurangnya implementasi dan aktualisasi dasar-dasar hukum tersebut dalam kehidupan sehari-hari. Maka dalam kajian ini dengan tema Lingkungan dan Pelestariannya dalam prespektif Islam, pada dasarnya adalah kajian umum yang mengkaji dari sisi hukum Islam, yaitu membahas secara umum pandangan Islam tentang lingkungan dan penyebab serta konsekuensi yang timbul dari kesalahan manusia dalam menangani masalah lingkungan serta bagaimanakah solusi yang diberikan oleh prinsip-prinsip Syariah Islam.
\end{abstract}

Key word : lingkungan, pelestarian, perspektif, hukum, Islam.

\section{PENGANTAR (INTRODUCTION)}

Keberadaan dan kondisi serta umur planet bumi ini dapat diketahui melalui bebatuan bumi yang ada di permukaannya yang menunjukkan bahwa usia bumi telah mencapai 4,6 miliar tahun. Pada awalnya, bumi merupakan batu besar yang panas menyala dan diliputi oleh batu-batuan yang menyala pula. Lalu, ada jutaan meteor yang menghantam permukaan bumi setiap hari, benturan-benturan tersebut meretakkan bumi, lalu membentuknya menjadi seperti bola. Beberapa waktu kemudian, suhu bumi berangsur-angsur dingin. Lalu, di lapisan udara mulai muncul uap air yang tebal mengelilinginya. Kemudian awan mendung terbentuk dan hujan turun dengan deras, hal ini menyebabkan pendinginan bumi dan timbulnya lautan, hingga menutupi bumi secara keseluruhan. Kemudian kulit bumi mulai terbentuk. Di atas kulit bumi ini muncul rekahan-rekahan yang disebut dengan lempengan bumi. Lempengan-lempengan ini bergerak dan berbenturan satu sama lainnya hingga membentuk gunung-gunung dan sungaisungai. (Britannica CD-ROM.2, entry "Big Bang")

Para ilmuwan berasumsi bahwa kehidupan di bumi ini dimulai sejak tiga miliar tahun silam. Menurut mereka, setelah itu kepunahan sejumlah makhluk hidup terjadi secara mendadak. Misalnya, dinosaurus yang punah 65 juta tahun silam setelah mereka melakukan kerusakan di muka bumi, melakukan pembunuhan dan pertumpahan darah satu sama lain. Kemudian, meteor besar turun dan membuat lubang di lapisan udara (atmosfer) bumi, hingga menyebabkan kebakaran, kehancuaran dan polusi. Dengan deikian, hancurlah seluruh makhluk yang ada di bumi. (Thalabah et.al., 2009)

\section{Polusi kembali terjadi}

Para ilmuwan dalam penelitiannya mengemukakan bahwa bumi dicemari oleh gas beracun dalam jumlah yang sangat besar ketika pertama kali diciptakan. Saat itu belum ada oksigen, seperti sekarang ini. Dengan demikian, lapisan udara saat itu merupakan kumpulan gas beracun dan uap air. Kemudian, setelah ada selama jutaan tahun, segbagai hasil dari aktivitas fisika yang telah ditetapkan Allah SWT, maka udara bumi dibersihkan secara keseluruhan dari gas-gas beracun itu, lalu dipenuhi dengan udara bersih. Begitulah Allah SWT memperbaiki bumi untuk kehidupan, agar bumi menjadi layak dihuni. 
Para ilmuwan mengatkaan bahwa kandungan gas karbon dan gas metan pada masa dahulu jumlahnya ratusan kali lebih besar dari yang ada sekarang. Ini artinya telah terjadi kerusakan besar pada udara bumi. Lalu Allah SWT memperbaikinya dengan menumbuhkan tanaman-tanaman yang memanfaatkan gas-gas beracun ini untuk mengolah makanan, juga dengan mencairkan gas-gas itu diberbagai samudara. Pada saat yang sama, Alah SWT. menciptakan makhluk-makhluk pengurai berupa bakteri-bakteri yang menghasilkan oksigen dalam jumlah besar. Ativitas ini berlangsung selama jutaan tahun. Bakteribakteri serta tumbuhan-tumbuhan ini menjadi perangkat pembersih udara bumi.

Namun dengan kasih sayangNya, Allah SWT telah membersihkan bumi kita dari gas karbon beracun. Dalam beberapa kurun waktu terakhir, gas ini memenuhi bumi dalam kadar yang tinggi. Lalu, kadarnya turun hingga mencapai $0,0035 \%$. Dengan kata lain, dalam setiap 100 ribu gram udara, terdapat 35 gram gas karbon.

Jika diperhatikan planet-planet dalam sistem tata surya, dapat disimpulkan bahwa udaranya buruk dan tidak layak untuk kehidupan. Sebagai contoh, kadar gas karbon yang ada di permukaan planet Mars mencapai 95\%, sedangkan pada planet Venus lebih dari 98\%. Tentu saat kita sadar bahwa kadar gas karbon yang ada di bumi ini rendah, hal ini merupakan kasih sayang Allah kepada kita.

Dalam penelitian yang dilakukan di Universitas Chicago, para ilmuwan berkeyakinan bahwa gas karbon pada hakikatnya adalah nikmat yang diberikan Tuhan Sang Pencipta. Gas ini berfungsi mengatur suhu panas di permukaan bumi. Perubahan kadar gas ini akan menyebabkan bencara alam dan badai (Thalabah et.al., 2009).

\section{Nikmat Allah pada oksigen}

Mengapa Allah SWT menentukan bahwa kadar oksigen di permukaan bumi ini sebesar 21\%? Tentu ini terkait dengan keberlangsungan kehidupan di dunia. Para peneliti berpendapat bahwa seandainya kadar oksigen di lapisan udara lebih kecil dari $15 \%$, maka api tidak akan menyala. Karena, kandungan oksigen tidak akan cukup untuk melakukan interaksi. Seandainya kadar oksigen mencapai lebih dari $25 \%$, maka segala yang ada di dunia akan hangus tanpa perlu disulut api, cukup dengan panas matahari saja.
Hal yang aneh dan membuat para ilmuwan kagum adalah bahwa jika semua makhluk di bumi terkena cahaya matahari secara langsung maka mereka akan mati dengan cepat. Akan tetapi, Alah SWT membekali lapisan udara dengan gas ozon karena kasih sayangNya. Lapisan ini menyerap cahaya ultraviolet yang muncul dari matahari. Jika tidak ada lapisan ini, pasti semua makhluk yang ada di bumi telah mati sejak lama, bahkan tidak mungkin ada kehidupan sampai kapan pun. Karena itu muncul pertanyaan, bagaimana mungkin para ilmuwan mengetahui kadar oksigen atau karbon di lapisan udara yang ada jutaan tahun yang lampau, para imuwan membuktikannya dengan mengambil sampel dari tanah keras yang membuat gelembung gas di pegunungan Alpen. Setelah meneliti gelembung-gelelmbung ini beserta elemenelemen yang terkandung di dalamnya, mereka mampu memperkirakan usia gelembunggelumbung, dan keadaan udara yang ada pada waktu itu.

Studi yang pernah dilakukan para ilmuwan menunjukkan bahwa kadar gas karbon di udara saat ini lebih besar $30 \%$ bila dibandingkan dengan beberapa masa sebelumnya. Adapun kadar gas methan lebih besar $100 \%$ dari tahun-tahun lampau. Kadar gas karbon diperkirakan meningkat sekitar $1 \%$ setiap tahunnya. Pertambahan ini sangat berbahaya bagi kehidupan manusia. Pertambahan yang cepat ini diakibatkan oleh aktivitas manusia dalam pembakaran dan produksi atom. Oleh karena itu, jika pertambahan ini terus terjadi sebagaimana saat ini, maka kadar gas karbon di udara dalam jangka waktu seratus tahun ke depan akan lebih tinggi dari pada apapun, dalam sejarah bumi satu juta tahun terakhir. Pertambahan kadar gas karbon ini menjadi sebab terjadinya perubahan iklim secara mendadak, dan hal ini bisa mengakibatkan berbagai bencana alam. Akan terjadi bencana kelaparan yang khususnya akan menimpa daerah-daerah miskin karena dilanda kekeringan. Permukaan air laut naik beberapa meter akibat mencairnya gunung-gunung es di kutub Utara dan Kutub Selatan. Ini akan menyebabkan keseluruhan sebagai ekses dari peningkatan air laut yang tinggi (Thalabah et.al., 2009).

Pertambahan gas karbon di udara bumi pada masa-masa silam terjadi akibat fenomena geologi seperti gunung berapi dan gas-gas yang dikeluarkannya. Namun gas-gas beracun yang 
dilontarkan gunung berapi di masa lalu tidak lebih besar dari polusi yang disebabkan oleh manusia sekarang ini.

Uraian di atas mendiskripsikan kondisi bumi yang membutuhkan pelestariannya disisi lain Islam telah memiliki aturan yang menjunjung tinggi keseimbangan dan kelestarian lingkungan. Namun sejauh ini para ulama belum banyak mengeksplorasi dan membangun argumen-argumen multiperspektif, holistik dan komprehensif tentang urgensi pelestarian lingkungan yang berbasis Islam.

Sebab agama tidak lagi hanya berkutat pada masalah-masalah spiritual dan eskatologis belaka, tetapi juga harus beranjak ke aspekaspek riil masyarakat pemeluknya, maka caranya adalah dengan menanamkan nilai-nilai moral sehingga manusia memiliki kemampuan tinggi untuk mengatasi masalah-masalahnya dengan tanpa merusak harmoni dengan lingkungannya.

\section{METODE ANALISA}

Kajian ini mencari rumusan konsep pelestarian lingkungan sebagai tujuan tertinggi syariah untuk memperkuat kapasitas fikih Islam dalam isu-isu ekologi dari sumber-sumber utama Islam (al-Quran dan Hadis). Analisis yang tepat untuk digunakan adalah content analysis (analisis isi). Analisis isi ini dipakai dalam pembacaan teks-teks (nushus) Al-Quran, Hadis yang relevan.

Content analysis sesunggunya sebuah metodeanalisis teks dalam konteks wacana berita media, namun demikian ia bisa dipakai untuk menganalisis teks-teks pada umumnya. Menurut Fairclough, analisis tekstual mencakup bentuk-bentuk analisis linguistik, seperti analisis vokabulari dan semantik, gramatikal serta sistim fonologi dan penulisan. Selain itu bagaimana sebuah kalimat di hubungkan dengan kalimat lainnya sehingga membentuk suatu artikel tertentu juga masuk dalam cakupan analisis tekstual (Fairclough, 1995).

\section{HASIL (RESULT)}

Al-Qur'an sebagai sumber ajaran Islam banyak mengungkap isu-isu lingkungan, bahkan Murad W. Hofmann menyatakan bahwa secara eksternal banyak surah al-Qur'an yang dinamai dengan nama hewan atau fenomena alam. Seperi surah al-Baqarah (sapi), al-Ra'ad (halilintar), al-Nahl (lebah), al-Anfal (binatang ternak), al-Naml (semut) dan lain-lain. (Hofmann, 1993) nama-nama ini adalah komponen lingkungan yang membentuk ekosistem. Meski nama-nama surah itu tidak memberi rincian untuk aplikasi perlindungan lingkungan secara eksplisit, namun itu cukup kuat memberi isyarat kepedulian Islam terhadap lingkungan.

Namun secara spesifik al-Quran menyebutkan beberapa prinsip tentang perlindungan lingkungan seperti larangan hidup boros dalam surat al-A'raf ayat 71 :

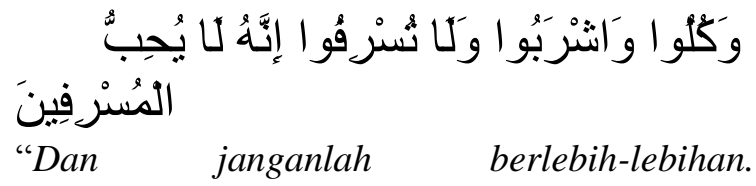
Sesungguhnya Allah tidak menyukai orangorang yang berlebih-lebihan."

Dan dalam surat al-Isra' ayat 26-27:

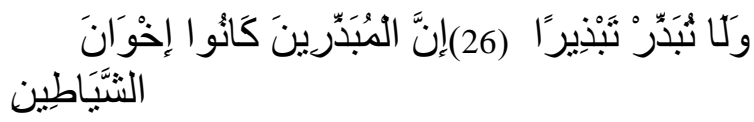

"Dan janganlah kamu menghambur-hamburkan (hartamu) secara boros. (26) Sesungguhnya para pemboros itu adalah saudara syaitan dan syaitan itu adalah sangat ingkar kepada Tuhannya".

Kemudian tentang mengelola bumi dengan penuh tanggung jawab seperti dalam surat al-An'am ayat 165

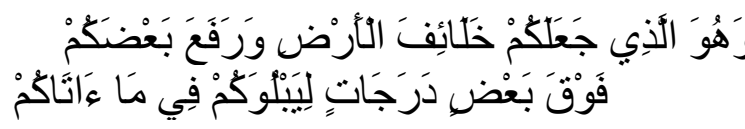

"Dan Dialah yang menjadikan kamu penguasapenguasa di bumi dan Dia meninggikan sebahagian kamu atas sebahagian (yang lain) beberapa derajat, untuk mengujimu tentang apa yang diberikan-Nya kepadamu.

Dalam konteks yang berbeda, perhatian al-Quran menampakkan sebuah visi ekologis yang bisa menjadi prinsip etis tentang penyelamatan lingkungan demi keberlanjutan kehidupan antar generasi. Selain al-Quran, visi hijau juga terdapat dalam banyak hadis. Yaitu ketetapan Nabi Muhammad Saw berkenaan dengan masalah-masalah lingkungan. Seperti hadis Nabi yang menyebutkan bahwa "Ada tiga hal yang dapat menyegarkan pandangan mata: melihat kehijauan, air hujan, dan wajah yang indah". (Bihar al-anwar,) hadis ini memberi landasan etis tentang perlunya memelihara tanaman sehingga menampakkan kehijauan lingkungan, mengelola air agar tidak tercemar demi kelangsungan hidup, dan menjaga kesehatan wajah yang bila ditafsirkan sebagai manifestasi dari citra manusia sehat. 
Hadis tentang etika terhadap binatang dalam penyembelihan yang diriwayatkan oleh Muslim menyebutkan: ".. dan bersikap santunlah dalam menyembelih. Tajamkanlah pisaumu (agar kamu) bisa menolong (meringankan rasa sakit) binatang sembelihanmu". Hadis ini memberikan pedoman moral dalam memperlakukan binatang yang dalam arti luas berarti tidak boleh menyakiti atau pun berburu binatang untuk kesenangan. Membunuh binatang pada dasarnya, dilarang sampai ada alasan yang membenarkan. Perintah ini bisa ikut mempertahankan biodiversity.

Dari hadis yang diriwayatkan oleh alTirmidzi menyebutkan: "Barang siapa menebang pohon (tanpa alasan yang membenarkan), Tuhan akan mengirimnya ke neraka". Hadis ini menurut Qardhawi (1977) adalah dalam konteks proteksi atas sumbersumber alam dan menjaga keseimbangan yang ada di antara makhluk hidup di dalam lingkungan. melalui optik ecothinkers, maka tanaman, terutama hutan adalah paru-paru dunia yang dapat menyeimbangkan atau setidaktidaknya menahan laju polusi (Hadi S. Alikodra, 2008) karena itu, selayaknya seorang muslim memperhatikan perintah ini dan wajib mengaplikasikannya, sebab hal ini memiliki implikasi signifikan bagi pelestarian lingkungan.

\section{PEMBAHASAN}

\section{Lingkungan hidup dan dampaknya terhadap manusia:}

Lingkungan dalam Kamus Besar bahasa Indonesia adalah daerah atau kawasan, bagian atau wilayah, semua yang mempengaruhi pertumbuhan manusia atau hewan.(Kamus Besar, 1991). Dalam bahasa Arab disebutkan dengan kata al-bi'ah yang merupakan kata masdar berasal dari kata $b a$ $w a-a$, dan dari kata $b a^{\prime} a-y a b u ' u$ dan dari kata bawwa'a. Sehingga orang Arab mengatakan bawwa'a ar-ramhu berarti fokus terhadap target atau mengenai sasarannya. Dan juga disebutkan dengan tabawwa'a: yang diasumsikan dengan arti turun dan tinggal (sebagai kata kerja yang tidak memerlukan objek), dan dapat menjadi kata kerja yang memerlukan objek tapi dengan kata keterangan seperti kata tasharruf fil mal; yang berarti mengatur keuangan. Dan inilah kata yang digunakan dalam Al-Qur'an dan bahasa Arab sebagai kata kerja muta'addi (memerlukan objek), seperti firman Allah أن) تبو"َ Ambillah olehmu berdua beberapa buah rumah di Mesir untuk tempat tinggal bagi kaummu", (Surat Yunus, ayat 87). Dari kata tabawwa'a dalam ayat di atas berarti; mengambil rumah atau mendirikan rumah.

Ada yang mengkategorikan kata $b a^{\prime} a$ dari bagian kata kerja seperti aba'ahu manzilan yang berarti menyiapkan dan menetap di dalam والذين تَبََّّو الآَّارَ والإيمان ( ...) "Dan orang-orang yang telah menempati Kota Madinah dan telah beriman, yaitu, orangorang yang tinggal di kota dan hati mereka telah mantap untuk beriman kepada Tuhan”.(Surat al-Hasyr, ayat 9). Maka rumah merupakan tempat tinggal secara materi sedangkan keimanan merupakan rumah secara و الذين آمنوا Daknawi. Dalam surat lain disebutkan

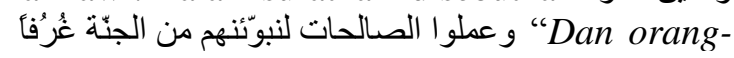
orang yang beriman dan mengerjakan amalamal yang saleh, sesungguhnya akan Kami tempatkan mereka pada tempat-tempat yang tinggi di dalam surga," yaitu membuat kamar tempat mereka di surga. (Surat al-Ankabut, Ayat 58). Dan telah digunakan kata tabawwa'a dalam sejumlah percakapan, seperti yang diriwayatkan dari Sabda Nabi Saw. من كذَب عليَ متعددأ فليتبوّه مقعده من النار berbohong atas namaku maka ia akan menempati neraka,(Al-Kilini, 1990: 62). yaitu, ia akan menempati rumahnya yang disediakan di dalam neraka. Dan kata $b a$ 'ah dapat berarti mampu dalam pernikahan, disebut demikian karena laki-laki adalah orang yang bertanggung jawab untuk menafkahi keluarganya dan dirinya sendiri kemudian ia berhak menggauli istrinya sebab istri adalah tempat untuk kasih sayang, sebagaimana Allah berfirman هنّ لباس لكم وأنتم "mereka (istri-istrimu) adalah pakaian kamu dan Anda (suami) adalah pakaian mereka",( Surat Al-Baqarah: Ayat 187). Ayat ini sangat relevan untuk pria ataupun wanita. Dalam Hadis Rasulullah Beliau bersabda: من استطاع منكم الباءة فليتزوّ"ج (Barangsiapa di antara kalian yang sudah mampu hendaknya ia segera menikah), dan maksud dari kata ba'ah disini adalah: pernikahan atau perkawinan. Sedang arti istiba'a ahluhu berarti seorang perempuan yang diambil oleh laki-laki menjadi keluarganya, sebagaimana yang mereka katakan istaba'a al makan; yaitu jika seseorang mengambil suatu lokasi untuk dijadikan tempat tinggal. (al-Ishfahani: Tth.)

Dengan demikian makna bi'ah atau lingkungan yang berarti tempat turun atau tempat tinggal terkadang menjadi sebab dan terkadang sebagai akibat. Namun kata al-bi'ah 
sering digunakan pada hal-hal yang didengarkan, dilihat, dirasa, atau yang diraba sehingga hal ini mencakup seluruh fenomena alam yang diciptakan Allah SWT seperti, darat dan laut, gunung, pohon, gunung berapi dan lainnya, bahkan termasuk hasil kreasi manusia seperti kota yang terdapat banyak perumahan dan berbagai bangunan yang megah, penataan pepohonan dan bunga dan lain sebagainya, maka yang pertama dapat disebut lingkungan alami dan yang kedua disebut lingkungan buatan. Sebagaimana halnya terdapat lingkungan perkotaan dan lingkungan pedesaan, atau dapat disebut juga dengan istilah lingkungan sosial, lingkungan ekonomi, lingkungan politik atau lingkungan keagamaan dan yang lainnya. Maka istilah ilmiah untuk lingkungan, dapat diartikan dengan segala sesuatu di luar dari diri manusia atau hewan, atau sejenisnya, yang terkait dengan seluruh kehidupan.

\section{Makna lingkungan secara holistik}

Dari definisi di atas sementara dapat disimpulkan bahwa lingkungan dalam pengertian umum adalah suatu keadaan yang dipengaruhi oleh faktor eksternal dan internal, maka lingkungan meliputi objek dari kondisi manusia, hewan atau tumbuhan dan termasuk pengaruh eksternal meliputi: pengaruh alam, darat, laut, udara, tanaman, dan sosial manusia. Yaitu, salah satu kondisi yang saling terkait satu sama lain, dan berinteraksi dan saling mempengaruhi, dalam arti bahwa jika ada perubahan salah satu faktor tersebut maka akan berimplikasi pada sistem lain secara sistemik sesuai dengan ketentuan Allah SWT (sunnatullah) pada alam ini.

Seperti suatu keadaan jika udara menjadi dingin di bawah keadaan normal maka akan berjangkit beberapa penyakit, dan jika pohon berlimpah, dan daerah perairan lebih luas maka suhu udara lebih rendah. Oleh karena itu Lingkungan merupakan unit kesatuan yang terintegrasi dengan banyak ilmu, dari bidang politik, sosial ekonomi dan sebagainya. Maka lingkungan dalam arti luas, mencakup lingkungan genetik, sosial, budaya, ekonomi dan lingkungan yang natural.

Sebagai contoh pada lingkungan sosial, jika kemiskinan dan kekurangan gizi yang melanda pada suatu keluarga akan menyebabkan orang tua terutama pada ibu hamil sehingga mempengaruhi kesehatan pada janin. Maka lingkungan yang sangat berpengaruh pada janin adalah rahim, sebab ia juga dapat dipengaruhi oleh lingkungan internalnya, dan ketika hadir ke dunia ia mulai menghadapi perjalanan panjang pada lingkungan baru yaitu lingkungan eksternal sebab ia akan berinteraksi dengan semua jenis makhluk. Dan kehidupan bayi dimulai dari saat kelahirannya kemudian berinteraksi langsung dengan lingkungan baru, dan melalui perkembangan ini sampai batas tertentu akan terbentuk kepribadian dan psikologinya sehingga tampak arah dan tujuan nilai-nilai keimanan yang ia yakini. Maka lingkungan sosial merupakan pembentuk kepribadian seseorang, jika lingkungan ini merupakan lingkungan agamis yang baik maka akan menumbuhkan kepribadian keimanan yang baik pada diri anak, dan jika lingkungan yang mempengaruhi pada anak adalah hal-hal yang buruk maka akan tumbuh kepribadian yang menyimpang pada diri anak.

Sedangkan pendidikan dari keluarga adalah dasar dalam pembentukan lingkungan sosial, jika ibu seorang yang beriman, maka ia akan membesarkan anak dalam keimanan. Namun sebaliknya jika ibu tidak dari lingkungan yang baik maka Rasulullah Saw. bersabda: إياكم وخضر اء الدمن "Hati-hati dengan tempat yang hijau" (Shoduq, 1425 H). Khadhra' addiman sebagaimana dijelaskan oleh Rasulullah Saw. adalah wanita cantik yang tumbuh di tempat yang buruk. Lingkungan dan keturunan berpengaruh pada anak serta berdampak pada ibu dalam pembentukan moral dan etika yang seimbang dengan kewajibannya. Seorang wanita yang cantik misalnya, jika tidak konsisten dengan aturan agamanya maka akan menjadi bencana sebab kecantikannya dan juga bagi suaminya, lebih-lebih bagi anak-anak dan keluarganya.

Maka angin yang harum akan menebarkan aroma yang harum seperti seseorang melewati taman bunga, demikian juga akan menebarkan bau tidak sedap ketika seseorang melewati tempat kotor. Sedangkan masalah-masalah sosial dan ekonomi juga memiliki dampak yang signifikan pada dimensi pendidikan anak-anak sehingga dapat menyebabkan keterbatasan kemampuan dari segi berfikir dan kesehatan mental yang mempengaruhi jiwa anak-anak.

Dengan demikan pembahasan lingkungan mencakup aspek genetika pada manusia, karena unsur pembentuk lingkungan adalah manusia dan di mana ia hidup, oleh 
sebab itu setiap anak yang terlahir dari rahim ibunya akan membawa unsur genetika yang menurun kepada anak dalam setiap sel dalam tubuhnya sehingga mempengaruhi sifat dan bentuk fisik seseorang, seperti mata, warna kulit, postur tubuh dan golongan darah serta kecerdasannya, dan bahkan dapat menerima gen yang bersifat negatif seperti jika sesorang mempunyai penyakit tertentu maka akan dibawa oleh si anak hingga dewasa dan juga berpengaruh pada sikap mental dan kejiwaan anak secara psikologis, maka agama Islam datang untuk menegaskan melalui beberapa riwayat hadis secara khusus, dengan menyebutkan makanan-makanan tertentu yang dianjurkan bagi ibu hamil agar membawa dampak positif bagi anak. seperti disebutkan dalam sebuah riwayat bahwa seseorang yang mengkonsumsi buah safarjal (dalam bahasa inggrisnya) quince maka akan mempengaruhi pada ketampanan janin. Sebagaimana disabdakan oleh Rasulullah Saw. : "Makanlah buah safarjal dan saling memberilah diantara kalian sebab akan menumbuhkan kasih sayang dalam hati, dan berikanlah pada istrimu yang sedang hamil karena hal itu akan berdampak baik bagi anak-anakmu" (al-khoroithi, 2006). demikian halnya beberapa riwayat yang menyatakan keutamaan susu, bahwa Rasulullah Saw. Bersabda; "Berilah minum susu kepda istrimu yang sedang hamil, karena akan mencerdaskan otak bayi" (al-khoroithi, 2006).

Aspek lingkungan sosial telah mempengaruhi pertumbuhan anak, sebagaimana diyakini oleh para psikolog bahwa dampak pertumbuhan dan kecerdasan anak sangat terpengaruh dengan kebiasaan sejak janin, lebih-lebih pada masa pertumbuhan anak-anak. Bahkan ada yang berpendapat bahwa kemampuan sosial manusia terbentuk sejak umur dua tahun dan mencapai kesempurnaan pada umur delapan tahun.Yang dimaksud dengan kemampuan sosial adalah kemampuan anak merespon segala sesuatu di sekelilingnya, mulai menyerap pengetahuan dan mulai meyakini sesuatu hingga merekam di dalam memorinya, dan dinyatakan oleh sekelompok ilmuwan bahwa keunggulan dalam bidang ilmu dan intelektual merupakan hasil dari pengaruh lingkungan budaya.

Sedang faktor lingkungan berupa keadaan alam mempunyai dampak yang signifikan terhadap kehidupan manusia, seperti seseorang yang tinggal jauh dari terik matahari di kutub utara atau selatan bumi ini misalnya, di mana udara dingin mencapai kira-kira tiga puluh di bawah nol derajat selsius, maka didapatkan dampak pada suasana hati mereka dan sikap yang dipengaruhi oleh suhu dingin biasanya, yaitu berpengaruh pada postur tubuh mereka lebih besar dan warna kulit mereka biasanya putih sedangkan rambut mereka biasa lurus. Tetapi jika seseorang yang tinggal dekat dengan garis khatulistiwa, dan daerah yang banyak terkena sinar Matahari maka suasana dan sikap mereka dipengaruhi oleh suhu yang panas dan kulit mereka cenderung berwarna coklat, dan dari segi prilaku mereka mungkin akan berbeda sebab suasana panas mempengaruhi perasaan mereka sehingga sikap mereka juga mempunyai karakteristik tersendiri, dan masih banyak lagi contoh dampak lingkungan alam terhadap manusia. Intinya adalah bahwa lingkungan budaya dan alam sangat berpengaruh pada segala aspeknya, lingkungan dan iklim memiliki dampak yang besar dalam kepribadian dan karakter manusia, sehingga memberikan pengaruh yang signifikan pada kebiasaan dan tindakan manusia.

Jelas bahwa unsur-unsur iklim yang mempengaruhi tubuh atau fisik pada manusia adalah faktor panas atau lembabnya suatu tempat, kering atau dinginnya suatu daerah, serta banyaknya angin dan radiasi matahari, atau faktor dekat atau jauhnya dengan pantai, dekat dan jauhnya seseorang dengan pegunungan dan sebagainya, oleh karena itu pada iklim panas di pegunungan dan sekitarnya kondisinya tetap dan konstan dalam keadaan dingin sedangkan terik matahari hanya menjadikan hangat.

\section{Islam dan Lingkungan}

Dalam prespektif Islam telah dijelaskan bahwa Islam mempunyai ketentuan-ketentuan tentang pelestarian lingkungan dengan menjelaskan sisi positif ataupun negatifnya, yaitu tentang kewajiban yang harus dilakukan ataupun yang dilarang terhadap lingkungannya. Baik yang dianjurkan atupun yang dibenci, sebagai contoh larangan berbuat kerusakan

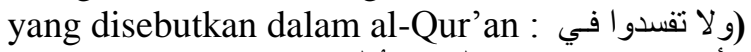

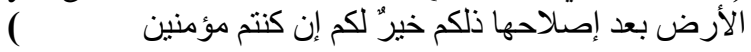
"janganlah berbuat kerusakan di bumi setelah perbaikan yang lebih baik. Yang demikian itu lebih baik bagimu jika betul-betul kamu orangorang yang beriman". (Surat al-A'raf: 85).

Dengan demikian perbuatan yang merusak lingkungan secara mutlak dilarang 
oleh Islam, apalagi dilakukan setelah adanya perbaikan maka menjadi sangat dilarang.

Sedagkan dari sisi perintah Allah

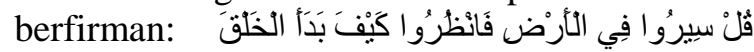
Katakanlah: "Berjalanlah di (muka) bumi, maka perhatikanlah bagaimana Allah menciptakan (makhluk) dari permulaannya" (Surat al-Ankabut; 20), di mana setiap individu sebagai orang yang berpikir akan mengamati hal-hal yang ia temukan dalam perjalanannya dimanapun ia berada, ketika ia melihat bagaimana diciptakan tanaman, hewan dan manusia, selain ketiga sumber tersebut juga pada penciptaan gunung yang menjulang dan lautan dengan ombaknya dan bebatuan pada tebing dengan berbagai macamnya, hal itu akan banyak ditemukan oleh setiap orang dan akan meyakinkan bahwa yang mencipktakan semua adalah Allah, hal ini akan didapatkan bagi setiap orang yang sering meneliti dan berfikir.

Hal di atas telah diperintahkan oleh Allah dengan berfirmannya: قل انظروا ماذا في : (Katakanlah: Perhatikanlah apa yang ada di langit dan bumi) (surat Yunus; 101). Manusia ketika melihat langit dan bumi serta alam semesta yang menakjubkan dengan lingkungan yang sangat serasi dalam dimensi waktu dan ruangnya serta keterkaitan antara ciptaan satu dengan yang lainnya menunjukkan adanya Maha Pencipta, sebagaimana Allah

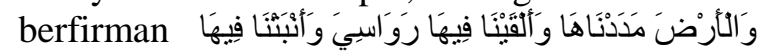
"Dan Kami telah menghamparkan bumi dan menjadikan padanya gunung-gunung dan Kami tumbuhkan padanya segala sesuatu menurut ukuran" (alHijr:19).

Sebagai pemikir, manusia melihat semua ciptaan Allah yang beraneka macam dengan keserasian dan saling keterkaitan antara satu ciptaan dengan yang lainnya, menunjukkan adanya satu Pencipta pada lingkungan yang terstruktur, dan terkait sehingga terdapat interaksi dan relevansi pada masing-masing ciptaan. Hal ini seseuai dengan firman Allah: الذي جعل لكم الأرض فر اشَّأو السماء بناءً وأنزل من السماء

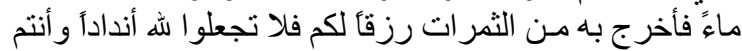
"Dialah Yang menjadikan bumi sebagai hamparan bagimu dan langit sebagai atap, dan Dia menurunkan air (hujan) dari langit, lalu Dia menghasilkan dengan hujan itu segala buah-buahan sebagai rezki untukmu; karena itu janganlah kamu mengadakan sekutu-sekutu bagi Allah, padahal kamu mengetahui". (Surat al-Baqarah ayat 22).
Sehingga dapat disimpulkan dari ayat di atas bahwa tidak ada sekutu bagi Allah dan Dia Maha Esa yang menciptakan dan mengatur seluruh alam semesta ini. Namun jika ada anggapan bahwa masing-masing ciptaan alam semesta ini ada penciptanya sendiri-sendiri seperti Dewa matahari dan Dewa bulan dan Dewa panas dan Dewa dingin dan Dewa laut dan Dewa tanaman dan sebagainya, atau ada yang menganggap dengan adanya dua dewa yaitu Dewa cahaya dan Dewa kegelapan, maka anggapan semua itu tidak benar bahkan dapat ditolak dengan alasan dan bukti akal sehat dan hati nurani. Karena jika setiap makhluk dibuat oleh tuhan yang berbeda sedangkan masingmasing mempunyai kehendak dan keinginnan yang berbeda pula maka akan terjadi ketidak serasian dan tidak akan ada keterkaitan antara satu dengan yang lainnya bahkan akan terjadi benturan dan bahkan kerusakan dalam alam semesta ini. Oleh karena itu Allah Yang

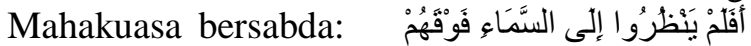

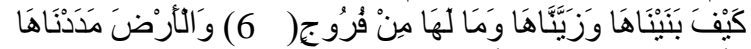

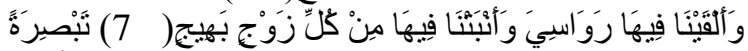

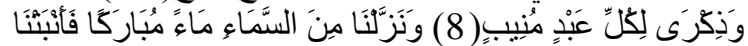

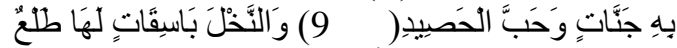

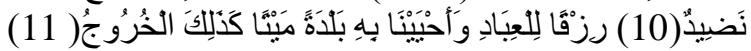
"Maka apakah mereka tidak melihat akan langit yang ada di atas mereka, bagaimana Kami meninggikannya dan menghiasinya dan langit itu tidak mempunyai retak-retak sedikitpun?(6) Dan Kami hamparkan bumi itu dan Kami letakkan padanya gunung-gunung yang kokoh dan Kami tumbuhkan padanya segala macam tanaman yang indah dipandang mata,(7) untuk menjadi pelajaran dan peringatan bagi tiap-tiap hamba yang kembali (mengingat Allah).(8) Dan Kami turunkan dari langit air yang banyak manfa atnya lalu Kami tumbuhkan dengan air itu pohon-pohon dan biji-biji tanaman yang diketam,(9) dan pohon kurma yang tinggi-tinggi yang mempunyai mayang yang bersusun-susun,(10) untuk menjadi rezki bagi hamba-hamba (Kami), dan Kami hidupkan dengan air itu tanah yang mati (kering). Seperti itulah terjadinya kebangkitan.(11)" (Surat Qaf: 6-11) Ayat-ayat ini dengan jelas menunjukkan pengaturan struktur yang serasi dari Yang Maha Kuasa dan dan Maha Pencipta. Dan tidaklah mungkin hal itu tejadi jika penciptanya terdiri dari jumlah yang banyak.

وإنْ

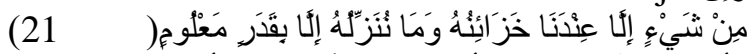

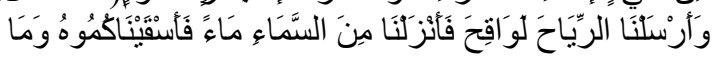


(22) 'Dan tidak ada sesuatupun melainkan pada sisi Kami-lah khazanahnya; dan Kami tidak menurunkannya melainkan dengan ukuran yang tertentu. Dan Kami telah meniupkan angin untuk mengawinkan (tumbuhtumbuhan) dan Kami turunkan hujan dari langit, lalu Kami beri minum kamu dengan air itu, dan sekali-kali bukanlah kamu yang menyimpannya. (Surat al-Hijr: 20-21), dengan demikian segala sesuatu di alam semesta ini mempunyai tempatnya masing hingga sekecil apapun benda itu, maka tempat untuk manusia adalah bumi ini dan disitulah ia beraktifitas dan berkembang.

Setiap makanan yang dikonsumsi oleh seseorang dari nabati atupun hewani maka akan diproses menjadi darah kemudian diproses dan berubah menjadi sperma sehingga jika bertemu dengan ovum maka dapat menjadi janin dan akhirnya dewasa menjadi manusia, demikian juga dalam penciptaan air laut, Matahari, bulan dan angin. Semua benda-benda ini, adalah dalam kekuasaan dan kontrol Allah SWT maka Allah menciptakannya dengan porsi dan ukuran yang sudah diketahui oleh Allah, dan dengan jumlah perkiraan yang terukur sesuai dengan kebutuhan manusia dan untuk kelangsungan hidupnya dalam lingkungan yang beraneka macam, seperti kebutuhan tanah beserta airnya, gunung, laut dan sungai beserta fauna yang ada di dalamnya. Maka Allah SWT berfirman; عَأنمن

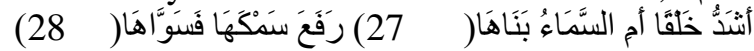

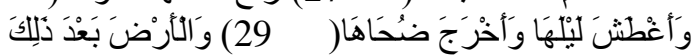

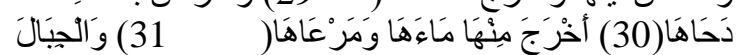

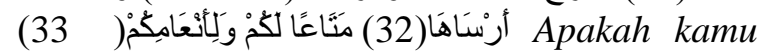
yang lebih sulit penciptaannya ataukah langit? Allah telah membangunnya (27), Dia meninggikan bangunannya lalu menyempurnakannya(28), dan Dia menjadikan malamnya gelap gulita dan menjadikan siangnya terang benderang (29), Dan bumi sesudah itu dihamparkan-Nya (30), Ia memancarkan daripadanya mata airnya dan (menumbuhkan) tumbuh-tumbuhannya(31), Dan gunung-gunung dipancangkan-Nya dengan teguh (32), (sетua itu) untuk kesenanganmu dan untuk binatang-binatang ternakmu (Surat an-Nazi'at: 27-32). Maka lingkungan alam ini mempunyai atap yaitu langit, dan mempunyai landasan yaitu bumi beserta isinya dan pelindungnya berupa malam dan siang, kondisi yang demikian inilah saling melengkapi sehingga manusia dapat hidup dengan sejahtera dan tercukupi segala kebutuhannya.
Dan dalam ayat yang lain Allah

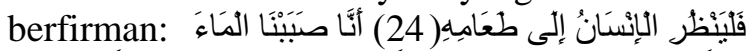

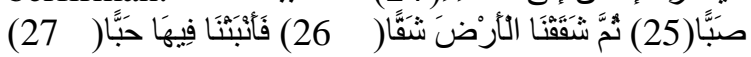

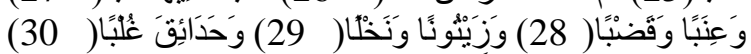

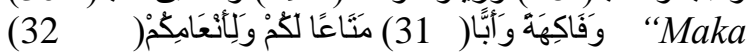
hendaklah manusia itu memperhatikan makanannya (24), Sesungguhnya Kami benarbenar telah mencurahkan air (dari langit) (25), kemudian Kami belah bumi dengan sebaikbaiknya (26), lalu Kami tumbuhkan biji-bijian di bumi itu (27), anggur dan sayur-sayuran (28), Zaitun dan pohon kurma (29), kebunkebun (yang) lebat (30), kebun-kebun (yang) lebat (31), dan buah-buahan serta rumputrumputan (32), untuk kesenanganmu dan untuk binatang-binatang ternakmu." (Surat Abasa: 24-32), dan segala sesuatu yang disebutkan dalam ayat ini dari adalah merupakan contoh bahwa manusia diperintahkan untuk selalu berfikir mulai dari makanan yang ia makan, yang bermula dari air sehingga muncul beraneka tanaman, bijian, buah-buahan tidak lain untuk menjamin kelangsungan hidup manusia.

Pada sisi lain Allah SWT berfirman:

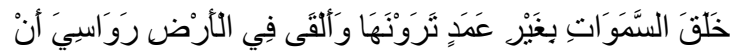

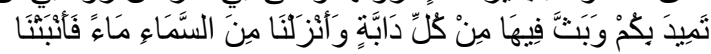
Dia menciptakan langit tanpa tiang yang kamu melihatnya dan Dia meletakkan gunung-gunung (di permukaan) bumi supaya bumi itu tidak menggoyangkan kamu; dan memperkembang biakkan padanya segala macam jenis binatang. Dan Kami turunkan air hujan dari langit, lalu Kami tumbuhkan padanya segala macam tumbuhtumbuhan yang baik. (Surat Luqman: 10) dalam ayat di atas menggunakan kata ganti perempuan (ha) pada kata "bi ghairi 'amadin taraunaha" yang berarti bahwa Allah menciptakan langit tanpa tiang sebagaimana kamu melihatnya. Maka tiang penyangga langit tidak diketahui secara kasat mata, hal ini sama halnya ketika kita tidak melihat secara kasat mata adanya gaya gravitasi antara planet. Disisi lain Allah memperkembangbiakkan segala jenis binatang di atas bumi ini, sehingga ada ilmuwan yang mengdentifikasi jumlah binatang yang berada di atas bumi ini hingga mencapai 30 juta jenis binatang, dan masing-masing jenis mempunyai sepesifikasi dan ciri-ciri khusus dari segi fisik ataupun prilakunya, hal itu disebabkan karena perbedaan lingkungan dimana mereka berkembang dan dari faktor makanan dan minumannya serta iklimnya, atau karean faktor eksternal lainnya. Seperti porsi makan mereka 
yang berbeda-beda ada yang rutin dan ada yang tidak menentu.

\section{Perintah Al-Quran dalam melestarikan lingkungan.}

Sebagaimana telah kita ketahui bahwa studi mutakhir tentang sejarah bumi menunjukkan bahwa lapisan udara bumi memiliki siklus. Dahulu bumi dipenuhi dengan gas beracun, lalu kadar gas beracun itu berangsur surut setelah melalui proses detail dan rumit. Selanjutnya proses perbaikan kerusakan lapisan udara bumi itu pun selesai secara keseluruhan. seandainya proses ini tidak dilakukan maka tidak akan ada kehidupan di permukaan bumi. Para ilmuwan mengatakan bahwa kadar polusi meningkat dalam beberapa waktu terakhir. (Mc Cormick,1991) Mereka menyampaikan peringatan kepada manusia untuk tidak mencemari bumi, karena hal itu dapat menimbulkan sejumlah bencana lingkungan. Padahal al Quran telah lebih dahulu menyampaikan fakta ilmiah ini dari pada para ilmuwan itu.

Al Quran menegaskan kepada kita bahwa bumi di masa lampau tidak layak untuk kehidupan. Kemudian Allah memperbaiki dan memerintahkan kita untuk tidak melakukan kerusakan di dalamnya. Allah juga memerintahkan kita untuk berdoa agar dihindarkan dari keburukan dan bencana-

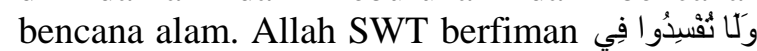

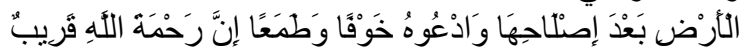
"Dan janganlah kamu membuat kerusakan di muka bumi, sesudah (Allah) memperbaikinya dan berdo alah kepada-Nya dengan rasa takut (tidak akan diterima) dan harapan (akan dikabulkan). Sesungguhnya rahmat Allah amat dekat kepada orang-orang yang berbuat baik." (QS al-A'raf:56)

Ayat di atas merangkum beberapa isyarat;

1. Agar kita tidak berbuat kerusakan di muka bumi dan mencemarinya. Hal ini tersirat

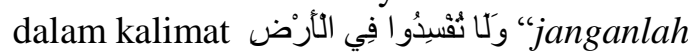
kalian membuat kerusakan di muka bumi"

2. Isyarat bahwa bumi pernah tercemari, lalu Allah memperbaiknya dan memerintahkan kita untuk tidak merusaknya setelah diperbaiki. Ini merupakan makna kalimat

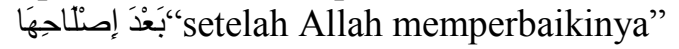

3. Isyarat akan pentingnya berdoa saat ini sebab di masa sekarang kerusakan lingkungan yang terjadi mengancam bumi dengan berbagai bencana alam seperti badai, tsunami, hujan asam, dan lain-lain.
وَادْعُوهُ خَوْفَاًا وَطَعَ'Berdoalah kepadaNya dengan rasa takut dan harapan."

4. Tidak berputus asa dari kasih sayang Allah, dan agar kita memohon diberikan kebaikan. Ayat ini juga mengandung isyrat bahwa Allah Maha Kuasa memperbaiki kerusakan

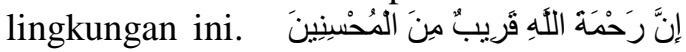
"Sesungguhnya rahmat Allah amat dekat kepada orang-orang yang berbuat baik."

Dalam konferensi iklim II yang dilaksanakan di Paris pada permulaan tahun 2007, lebih dari 500 ilmuwan yang berasal dari berbagai penjuru dunia mengeluarkan berbagai pendapat. Salah satu yang terpenting adalah bahwa kerusakan lingkungan dan polusi telah terjadi baik di daratan maupun lautan. Kerusakan itu telah melanda manusia, tumbuhan, dan hewan. Menurut mereka, semua kerusakan terjadi akibat ulah manusia. Ada kemungkinan lapisan udara bumi akan kembali diliputi banyak gas karbon. (Sayyed Hossein Nasr: 1984)

Yang menakjubkan adalah al-Quran telah merangkum semua pendapat ini hanya dengan satu ayat. Ayat itu menerangkan bahwa munculnya kerusakan di darat dan di laut disebabkan oleh perbuatan manusia. Allah

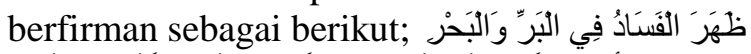

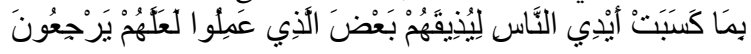
"Telah nampak kerusakan di darat dan di laut disebabkan karena perbuatan tangan manusia, supaya Allah merasakan kepada mereka sebahagian dari (akibat) perbuatan mereka, agar mereka kembali (ke jalan yang benar)." (QS al-Rum: 41)

Dari beberapa makna al-fasad yang terdapat dalam kamus al-Muhith adalah $a l-j a d b$ (ketidak suburan, kegersangan, kelaparan, paceklik). Al-Jadb muncul akibat berhentinya hujan atau karena bencana alam yang dapat membinasakan spesies tumbuhan dan hewan. Oleh sebab itulah Allah memerintahkan manusia untuk tidak menjadi penyebab dari kehancuran dan kerusakan udara bumi. Ini sesuai dengan firman Allah SWT dalam al

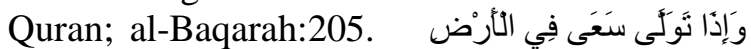

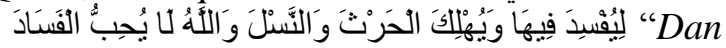
apabila ia berpaling (dari kamu), ia berjalan di bumi untuk mengadakan kerusakan padanya, dan merusak tanam-tanaman dan binatang ternak, dan Allah tidak menyukai kebinasaan."

Dengan demikian al-fasad (kerusakan itu ada bebarapa macam; kerusakan moral dan kerusakan lingkungan. Ayat-ayat di atas turun 
saat belum diketahui akan terjadinya tingkat polusi sangat tinggi dan juga ketika belum ada perigatan tentang kerusakan udara bumi

Dari uraian tersebut, dapat ditarik kesimpulan bahwa Allah SWT menciptakan bumi sebagai bentuk kasih sayangNya kepada kita. Dahulu bumi sangat tercemar, lalu Allah SWT memperbaikinya untuk kita. Dia menjadikan bumi tempat yang layak bagi kehidupan dan menyenangkan. Semua itu agar kita dapat tinggal di bumi dan mensyukuri nikmat Allah SWT.

\section{KEPUSTAKAAN}

Abdul Baqi, Muhammad Fu'ad. T.th. AlMu'jam al-Mufahras li alfadzh alQuran al-Karim. Maktabah Dahlan, Indonesia. Entry "biah"

Al-khoroithi, Abu Bakar Muhammad bin Ja'far bin sahal bin syakir asyamiri. 2006.

Makarimul Akhlak:, maktabah ar-rusyd. 171-172, 194.

Fairclough, Norman., 1995. Media Discourse. Edward Arnold, New York, 45.

Hofmann, Murad. 1993. Islam: The Alternative. Maryland: Amana Publications. 95.

Ishfahani, Raghib. T.t. Mu'jam Mufradat Alfadz al-Qur'an, T.tp. 63.

McCormick, John. 1991. Reclaiming Paradise: The Global Environtmental Movement. Bloomington: Indiana University Press. 182.

Nasr, Sayyed Hossein. 1984. The Encounter of Man and Nature. California: University of California Press. 17

S. Alikodra, Hadi. 2008. Global Warming, Banjir, dan Pembalakan Hutan. Bandung: Nuansa. 61.

Shoduq, 1425 H . Ma'ani al-akhbar, Muassasah Nasyr Al-Islami, cet. Ke-5. Jami'ah Qum Iran. 91.

Thalbah, Hisham (et.al), 2009. Ensiklopedia Mukjizat Alquran dan Hadis, Kemukjizatan Penciptaan Bumi (8). Ttp: Sapta Sentosa. 31-33,35

Tim Penyusun, 1991. Kamus besar Bahasa Indonesia, edisi kedua. Jakarta: Balai Pustaka. 596.

Qardhawi, Yusuf. 1977. Al-Sunnah Mashdaran lil-ma'rifati wal hadharah. Kairo: Dar al-Syuruq. 143-144. 